pastry crumbs. We recorded the temperature at $-23^{\circ} \mathrm{C}$.

28 January 1996 we recorded a temperature of $-35^{\circ} \mathrm{C}$. We noticed the warbler in and around dried clematis vines where we have a climbing trellis. In behind the trellis, our downstairs bathroom vent exits the house. I placed my hand near the vent and noticed a fair bit of warm air was escaping through the vent even though the fan was not running. The warbler would return to this area on the trellis, and in amongst the dried vines, spending a good part of the day just sitting.

29 January 1996 we recorded the temperature to be $-37^{\circ} \mathrm{C}$. The warbler was observed feeding.

2 February 1996 we recorded a temperature of $-40^{\circ} \mathrm{C}$. The warbler was feeding on small bits of suet dropped beneath the suet feeder.

We went on a short vacation to try and rid ourselves of some of the cold weather. We had sprinkled an abundance of ground suet and pastry crumbs for the bird if it managed to survive through this cold spell. We returned 27 February 1996. At daylight we checked the backyard to see if we could see the warbler and if it had survived. Sure enough, there it was feeding. It was not feeding near the house suet feeder as before, we have a second suet feeder located on a transplanted stump at the far end of the yard. This area is fairly well protected from the wind by a medium-sized spruce tree. The warbler was spending most of its time in the spruce trees. The warbler's feeding habits had changed also, we observed the bird feeding more like a warbler. A flicker was feeding on the suet feeder, and the warbler was perched a metre or so away. When a small piece of suet fell from the feeder loosened by the flicker, the warbler darted out and caught the small piece of suet. before it hit the ground, the warbler would return to the perch and sit. After the flicker had left, the warbler clung to the stump and fed on loosened pieces of suet. We recorded the temperature at $-21^{\circ} \mathrm{C}$.

4 March 1996 temperature $-15^{\circ} \mathrm{C}$. The warbler was observed in the backyard. We began to notice a change in the warbler's colouration. Previously we had noticed the throat was very light near white or buff white. We are noticing now that the throat is starting to take on a yellow hue. We also notice on the side of the bird, the streaks are becoming darker, and the yellow is becoming brighter.

16 March 1996, we have not see the warbler in nearly two weeks. The weather has warmed. American Robins are singing their territorial song.

- Evelyn and Joe Parsons, 1701 Ashgrove Road, Lethbridge, AB. T1K $3 \mathrm{M} 3$

\section{AN UNUSUAL LOGGERHEAD SHRIKE NEST LOCATION}

On 3 July 1996 I was conducting a Loggerhead Shrike survey in a 16 $\mathrm{mi}^{2}$ block for the Canadian Wildlife Service east of the town of Cessford. While glassing from high ground for likely Loggerhead Shrike habitat I noticed, approximately 1.5 miles away, what appeared to be a clump of shrub in the predorninantly grazed mixed grass prairie landscape. Since a vehicle trail led past it I decided to drive down for a look in the hope of finding it occupied by shrikes.

To my surprise it turned out not to 


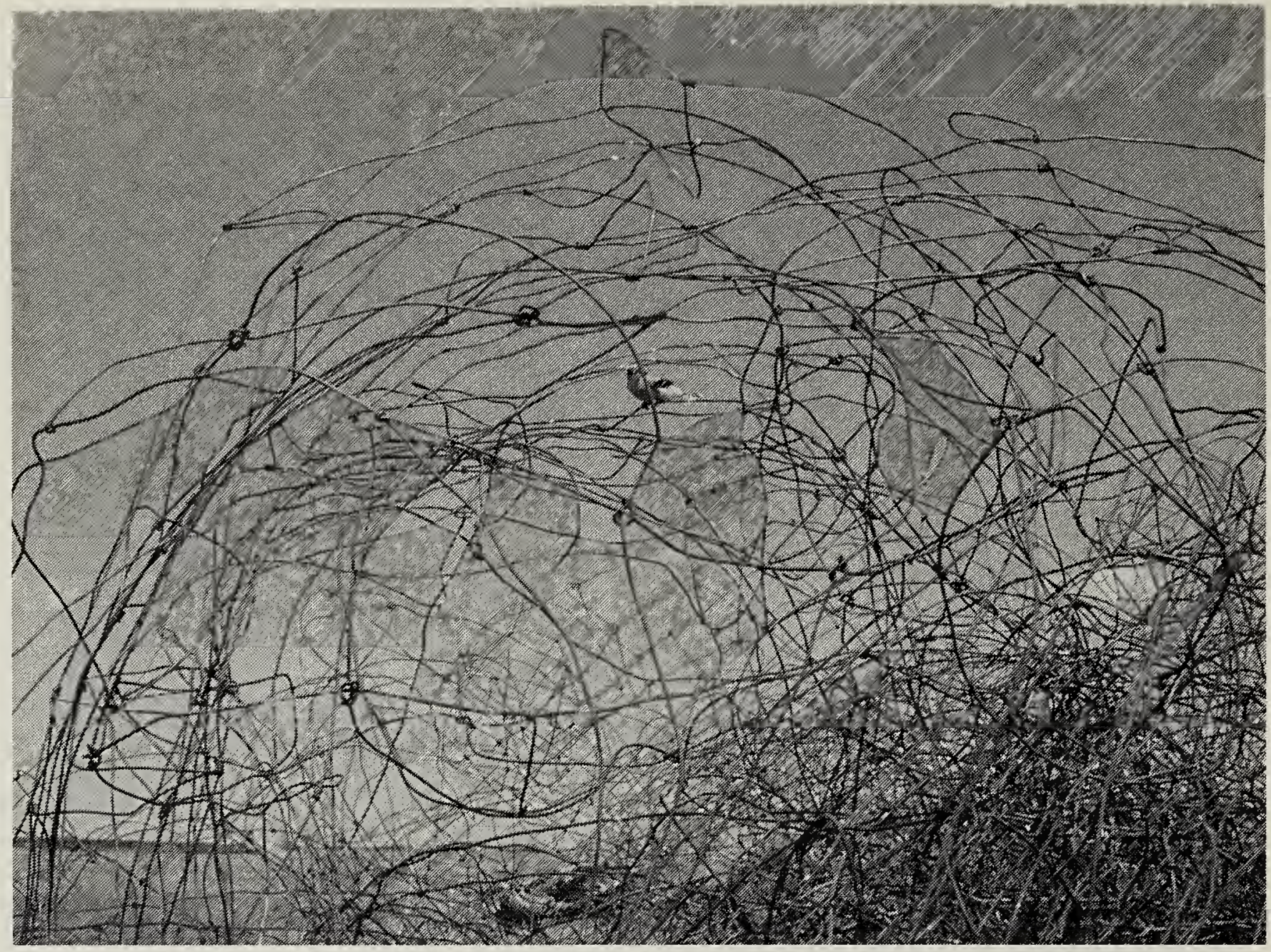

be a clump of shrub but a huge pile of discarded, rusty chain link fencing. As I approached I noticed two adult and four fledgling Loggerhead Shrikes perched all through the pile. While inspecting it I discovered their nest deep inside the wire tangle. It was down so far that I could not reach it with my hand and an attempt to photograph it failed. Although from a human aesthetical perspective it was a definite eyesore from the Loggerhead Shrike perspective, the pile of rusty wire supplied an acceptable nest location. A virtual fortress, safe from most predators except perhaps bull snakes and weasels. The precise location was UTM $12 \mathrm{U}$ 4621595649734.

I was rather amused since we often stress that Loggerhead Shrikes are highly selective in choosing their nest locations. Here in Alberta shrikes usially nest in isolated willow or thorny buffaloberry shrubs or at the outer perimeter of larger shrub clumps or caragana plantings (89\%). Other nest sites are in poplar, box elder, chokecherry, Japanese elm, wolfwillow, lilac, wild rose and tumbleweed accumulations. ${ }^{1,2}$ This is possibly the first observation of a shrike nest in an "artificial" structure. One of the joys and challenges of biology seems to be that every time we think we have our study subjects figured out, they manage to confound us once more.

1. COLLISTER, D.M. 1994. Breeding ecology and habitat preservation of the Loggerhead Shrike (Lanius ludovicianus excubitorides) in southeastern Alberta. Master's Degree Project, University of Calgary. $161 \mathrm{pp}$.

2. KILIAAN, H.P.L. 1993. Alberta Loggerhead Shrike fieldwork 1993. Unpublished report. Canadian Wildlife Service, Edmonton. 9 pp.

- Hendrik P.L. Kiliaan, Canadian Wildife Service, 4999 - 98th Avenue, Edmonton, AB. T6B $2 \times 3$ 